\title{
Clinical and laboratory associations of mannose-binding lectin in 219 adults with IgG subclass deficiency
}

\author{
James C. Barton ${ }^{1,2,3^{*}} \mathbb{D}$, Jackson C. Barton² and Luigi F. Bertoli' $2,3,4$
}

\begin{abstract}
Background: Mannose-binding lectin (MBL) deficiency may increase risk of respiratory tract infection in adults unselected for lgG or lgG subclass levels. In a retrospective study, we sought to determine associations of serum MBL levels with clinical and laboratory characteristics of unrelated non-Hispanic white adults at diagnosis of IgG subclass deficiency (IgGSD). We computed the correlation of first and second MBL levels expressed as natural logarithms (In) in a patient subgroup. We compared these characteristics of all adults with and without MBL $\leq 50$ $\mathrm{ng} / \mathrm{mL}$ : age; sex; body mass index; upper/lower respiratory tract infection; diabetes; autoimmune condition(s); atopy; other allergy; corticosteroid therapy; and subnormal serum IgG subclasses, IgA, and IgM. We performed logistic regression on $\mathrm{MBL} \leq 50 \mathrm{ng} / \mathrm{mL}$ (dichotomous) using the three independent variables with the lowest values of $\mathrm{p}$ in univariate comparisons.

Results: There were 219 patients (mean age $51 \pm 13$ y; 82.5\% women). Thirty-six patients (16.4\%) had MBL $\leq 50 \mathrm{ng} /$ $\mathrm{mL}$. Two MBL measurements were available in 14 patients. The median interval between the first and second measurements was $125 \mathrm{~d}$ (range 18-1031). For In-transformed data, we observed adjusted $r^{2}=0.9675$; Pearson correlation coefficient 0.9849 ; and $p<0.0001$. Characteristics of patients with and without $\mathrm{MBL} \leq 50 \mathrm{ng} / \mathrm{mL}$ did not differ significantly in univariate comparisons. We performed a regression on $M B L \leq 50 \mathrm{ng} / \mathrm{mL}$ using: subnormal $\operatorname{lgM}$ ( $p=0.0565)$; upper respiratory tract infection $(p=0.1094)$; and body mass index $(p=0.1865)$. This regression revealed no significant associations. Conclusions: We conclude that the proportion of the present IgGSD patients with serum $\mathrm{MBL} \leq 50 \mathrm{ng} / \mathrm{mL}$ is similar to that of healthy European adults. MBL $\leq 50 \mathrm{ng} / \mathrm{mL}$ was not significantly associated with independent variables we studied.
\end{abstract}

Keywords: IgG subclass deficiency, Mannose-binding lectin, Pneumonia, Respiratory tract infection, Sinusitis

\section{Background}

Mannose-binding lectin (MBL; mannan-binding protein or lectin) is involved in innate immune defense, is produced largely by hepatocytes, and is encoded by $M B L 2$ (chromosome 10q21.1). MBL is an oligomer that binds repeating sugar residues (especially D-mannose and $\mathrm{N}$-acetyl glucosamine oligosaccharides) expressed on the surfaces of diverse microorganisms [1]. MBL promotes killing of microorganisms by complement activation via

\footnotetext{
* Correspondence: ironmd@isp.com

'Department of Medicine, University of Alabama at Birmingham, Birmingham, AL, USA

${ }^{2}$ Southern Iron Disorders Center, 2022 Brookwood Medical Center Drive,

Suite 626, Birmingham, AL 35243, USA

Full list of author information is available at the end of the article
}

the lectin pathway and by opsonization [2]. Three common $M B L 2$ exon 1 mutations (sometimes designated as $B, C$, and D) encode unstable MBL polypeptides with subnormal molecular weight, blood levels, oligimerization, ligand binding, and complement activation [3, 4] and limited acute-phase responses to severe infection [5]. MBL2 promoter region haplotypes account for variability of blood MBL levels across race/ethnicity groups unexplained by exon 1 alleles [6]. In young male Finnish military recruits with or without asthma, MBL levels below the median were associated with significantly increased odds of respiratory tract infection, after adjustment for asthma status [7].

Immunoglobulin (Ig) G (IgG), synthesized by plasma cells, is the predominant of five classes of Igs in humans. 
Although the four IgG subclasses share 90\% amino acid identity, each subclass has different antigen binding, immune complex formation, complement activation, and half-life [8]. IgG subclass deficiency (IgGSD) in adults is characterized by: levels of IgG1-3 subclasses more than two standard deviations (SD) below the population mean; frequent or severe respiratory tract infection; suboptimal IgG responses to pneumococcal polysaccharides; and increased prevalence of autoimmune conditions $[9,10]$. A study of Dutch adults with recurrent respiratory tract infection revealed no significant clinical differences between subjects with or without MBL2 genotypes that predict low MBL production after subjects with subnormal serum Ig levels or suboptimal responses to 23-valent pneumococcal polysaccharide vaccine were excluded from the analyses [11].

We sought to determine associations of serum MBL levels with other characteristics of 219 consecutive unrelated non-Hispanic white adults at diagnosis of IgGSD in a retrospective study. We computed the correlation of first and second serum mannose-binding levels expressed as natural logarithms (ln) in a patient subgroup. We compared these characteristics of all patients with and without $\mathrm{MBL} \leq 50 \mathrm{ng} / \mathrm{mL}$ : age at diagnosis; sex; body mass index (BMI); upper and lower respiratory tract infection; diabetes; autoimmune condition(s); atopy; other allergy; corticosteroid therapy; and subnormal serum levels of IgG subclasses, IgA, and IgM (dichotomous variables). We also performed logistic regression on $\mathrm{MBL} \leq 50 \mathrm{ng} / \mathrm{mL}$ (dichotomous). We discuss characteristics of the present cohort and compare them with those of Caucasian white adults unselected for IgGSD who were evaluated for prevalence of low MBL levels (or corresponding MBL2 genotypes) and risk of respiratory tract infection.

\section{Methods}

\section{Patient selection}

We studied consecutive unrelated self-identified non-Hispanic white adults (ages $\geq 18 \mathrm{y}$ ) in a single outpatient referral practice who reported having frequent or severe upper or lower respiratory tract infection, were diagnosed to have IgGSD $[9,10,12]$ before 2 October 2018, and in whom serum MBL levels were measured. Frequent infection was defined as four or more episodes per year that required antibiotic therapy. Severe infection was defined as any infection that required in-hospital treatment.

The present study design did not include reviewing medical records of or otherwise recruiting adult control subjects from general clinic populations. We excluded patients with: common variable immunodeficiency; hypogammaglobulinemia due to B-cell neoplasms, organ transplantation, immunosuppressive therapy, anti-cancer chemotherapy, or increased Ig loss; malignancy; monoclonal gammopathy; infection with parasites, Mycobacterium sp., human immunodeficiency virus (HIV), Epstein-Barr virus, or cytomegalovirus; allergic bronchopulmonary aspergillosis; eosinophilic granulomatosis with polyangiitis (Churg-Strauss); ataxia-telangiectasia; rare immunodeficiency syndromes associated with elevated serum IgE levels; and incomplete evaluations.

\section{Other conditions}

BMI was computed as $\mathrm{kg} / \mathrm{m}^{2}$. We classified diabetes according to the criteria of the American Diabetes Association [13].

Upper respiratory tract infection was defined as reports of sinusitis, otitis media, mastoiditis, pharyngitis, and tonsillitis. Lower respiratory tract infection was defined as reports of bronchitis, pneumonia, and bronchiectasis.

Autoimmune condition(s), atopy (allergic asthma, allergic rhinitis, and allergic dermatitis/eczema) were diagnosed by referring physicians. Other allergy manifestations reported by patients included urticaria, angioedema, or anaphylaxis that occurred in association with specific medications, foods, or environmental allergens, or without exposure to known allergens [9].

We defined a dichotomous corticosteroid therapy variable: daily oral steroids for management of autoimmune condition(s); intermittent oral or parenteral steroids, usually to relieve manifestations of infection; or topical or inhaled corticosteroids, typically used intermittently for diverse indications [9].

\section{Laboratory methods}

Serum Ig levels were measured using standard methods (Laboratory Corporation of America, Burlington, NC, USA) before IgG replacement therapy was initiated. We defined mean $\pm 2 \mathrm{SD}$ as reference ranges for all Ig measurements $[9,14]$. Ig reference ranges are: IgG 7.0-16.0 $\mathrm{g} / \mathrm{L} \quad(700-1600 \mathrm{mg} / \mathrm{dL}) ; \quad \mathrm{IgG} 1 \quad 4.2-12.9 \mathrm{~g} / \mathrm{L} \quad(422-1292$ $\mathrm{mg} / \mathrm{dL}) ;$ IgG2 $1.2-7.5 \mathrm{~g} / \mathrm{L}(117-747 \mathrm{mg} / \mathrm{dL}) ;$ IgG3 $0.4-$ $1.3 \mathrm{~g} / \mathrm{L}(41-129 \mathrm{mg} / \mathrm{dL}) ; \mathrm{IgG} 40-2.9 \mathrm{~g} / \mathrm{L}(1-291 \mathrm{mg} / \mathrm{dL})$; IgA $700-4000 \mathrm{mg} / \mathrm{L} \quad(70-400 \mathrm{mg} / \mathrm{dL})$; and IgM $400-$ $2300 \mathrm{mg} / \mathrm{L} \quad(40-230 \mathrm{mg} / \mathrm{dL})$ [15]. Subnormal Ig levels were defined as those below the corresponding lower reference limits. Serum MBL levels were measured using an enzyme-linked immunosorbent assay (Laboratory Corporation of America, Burlington, NC, USA). Specific levels of $\mathrm{MBL} \leq 50 \mathrm{ng} / \mathrm{mL}$ were not reported.

\section{Statistics}

The analytic data set consisted of complete observations on 219 patients with IgGSD. For some analyses, MBL levels $\leq 50 \mathrm{ng} / \mathrm{mL}$ and $>4000 \mathrm{ng} / \mathrm{mL}$ were imputed as $49 \mathrm{ng} / \mathrm{mL}$ and $4001 \mathrm{ng} / \mathrm{mL}$, respectively. Descriptive data are displayed as enumerations, percentages, mean $\pm 1 \mathrm{SD}$, or median (range). Age, BMI, and total IgG data were normally 
distributed and their respective means were compared using Student's t-test (two-tailed). Means/medians of continuous data that were not normally distributed were compared using the Mann-Whitney $U$ test (two-tailed). Proportions were compared using Fisher's exact test (two-tailed). For some proportions, we computed the $95 \%$ confidence interval using continuity correction.

Retrospective chart review identified 14 patients in whom MBL was measured on different days. We computed and compared mean values of the first and second measurements. Because the range of $\mathrm{MBL}$ levels in adults is greater than three logs [6], we used the Pearson product-moment method to compute the linear correlation of the natural logarithms (ln) of the first and second measurements.

We compared these characteristics of patients with and without $\mathrm{MBL} \leq 50 \mathrm{ng} / \mathrm{mL}$ using univariate analyses: age at diagnosis; sex; BMI; upper and lower respiratory tract infection; diabetes; autoimmune condition(s); atopy; other allergy; corticosteroid therapy; and subnormal IgG1-4 subclass, IgA, and IgM levels. Because 36 patients had $\mathrm{MBL} \leq 50 \mathrm{ng} / \mathrm{mL}$, we selected the three independent variables with the lowest values of $\mathrm{p}$ in univariate comparisons for multivariable logistic regression on $\mathrm{MBL} \leq 50 \mathrm{ng} / \mathrm{mL}$ (dichotomous), in accordance with the "one in ten rule" [16]. Analyses were performed with Excel $2000^{\circ}$ (Microsoft Corp., Redmond, WA, USA) and GB-Stat ${ }^{\oplus}$ (v. 10.0, 2003, Dynamic Microsystems, Inc., Silver Spring, MD, USA). We defined values of $p<0.05$ to be significant. Bonferroni corrections were applied to control the type I error rate at 0.05 for multiple univariate comparisons.

\section{Results}

\section{Characteristics of 219 patients}

Mean age was $51 \pm 13$ y (median 52; range 18-90). There were 38 men (17.4\%). Mean BMI was $29.9 \pm 7.0 \mathrm{~kg} / \mathrm{m}^{2}$. Upper respiratory tract infection was reported by 199 patients $(90.9 \%)$. Lower respiratory tract infection was reported by 188 patients (85.8\%). Both upper and lower respiratory tract infection was reported by 170 patients (77.6\%). Thirty-four patients (15.5\%) had diabetes (type 1, $n=2$; type $2, n=32$ ).

Autoimmune condition(s) were diagnosed in 114 patients $(52.1 \%)$. The most common conditions were Hashimoto thyroiditis, rheumatoid arthritis, Sjögren syndrome, and systemic lupus erythematosus (Table 1). Twelve of 38 men $(31.6 \%)$ and 102 of 181 women (56.4\%) had autoimmune condition(s) $(p=0.1079)$. Atopy was diagnosed in 68 patients (31.1\%). Allergic asthma, allergic rhinitis, and allergic dermatitis/eczema were diagnosed in 60 patients, 14 patients, and 4 patients, respectively (Table 1$)$. Six patients $(2.7 \%)$ had two or more conditions classified as atopy. Ninety patients (41.1\%) had other allergies.
Seventy-eight patients (35.6\%) reported corticosteroid therapy (Table 1).

\section{MBL levels}

Mean MBL levels of patients aged $\leq 52$ y vs. $>52 \mathrm{y}$ at diagnosis did not differ significantly. Mean/median MBL levels of men were greater than those of women, but the difference was not significant $(1756 / 1542 \mathrm{ng} / \mathrm{mL}$ vs. $1229 / 789$ $\mathrm{ng} / \mathrm{mL}$, respectively; $p=0.1526$, Mann-Whitney $\mathrm{U}$ test). Respective mean MBL levels of patients with $\mathrm{BMI}<30.0$ $\mathrm{kg} / \mathrm{m}^{2}$ and those with BMI $\geq 30.0 \mathrm{~kg} / \mathrm{m}^{2}$ did not differ significantly. There was a weak negative correlation of $\mathrm{ln}$ MBL levels and BMI (adjusted $r^{2}=0.0218$; Pearson correlation coefficient $-0.1478 ; p=0.0288$ ).

Mean/median MBL levels of patients who did and did not report upper respiratory tract infection did not differ significantly. Mean/median MBL levels of patients who did and did not report lower respiratory tract infection did not differ significantly. Respective mean/median MBL levels of patients with and without diabetes, autoimmune conditions, atopy, other allergies, and corticosteroid therapy did not differ significantly.

\section{First and second MBL levels in 14 patients}

The median interval between the first and second $\mathrm{MBL}$ measurements was 125 days (range 18-1031). Mean/median first and second MBL levels $(1063 / 446 \mathrm{ng} / \mathrm{mL}$ and $885 / 420 \mathrm{ng} / \mathrm{mL}$, respectively) did not differ significantly. There was a highly significant positive linear correlation of first and second MBL levels (Fig. 1).

\section{Patients with and without $M B L \leq 50 \mathrm{ng} / \mathrm{mL}$}

Thirty-six of 219 patients (16.4\% [ $95 \%$ confidence interval 11.9, 22.2]) had MBL $\leq 50 \mathrm{ng} / \mathrm{mL}$ (Fig. 2). Characteristics of patients with and without $\mathrm{MBL} \leq 50 \mathrm{ng} / \mathrm{mL}$ did not differ significantly in univariate comparisons (Table 1). Proportions of IgG subclass immunophenotypes in patients with and without $\mathrm{MBL} \leq 50 \mathrm{ng} / \mathrm{mL}$ did not differ significantly (Table 2).

\section{Logistic regression on $M B L \leq 50 \mathrm{ng} / \mathrm{mL}$}

We performed a regression on $\mathrm{MBL} \leq 50 \mathrm{ng} / \mathrm{mL}$ using the three independent variables with the lowest values of $\mathrm{p}$ in univariate comparisons: subnormal $\operatorname{IgM}(p=$ $0.0565)$; upper respiratory tract infection $(p=0.1094)$; and body mass index $(p=0.1865)$ (Table 1$)$. This regression revealed no significant independent associations $(p$ $=0.7197$, subnormal IgM; $p=0.0679$, upper respiratory tract infection; and $p=0.1268$, body mass index) ( $p=$ 0.1734 for significance of the model).

\section{Discussion}

Serum MBL $\leq 50 \mathrm{ng} / \mathrm{mL}$ occurred in $16.4 \%$ of the present 219 patients. Twelve of 100 healthy Danish blood donors 
Table 1 Characteristics of 219 adults with IgG subclass deficiency ${ }^{1}$

\begin{tabular}{|c|c|c|c|}
\hline Characteristic & Mannose-binding lectin $\leq 50 \mathrm{ng} / \mathrm{mL}(n=36)$ & Mannose-binding lectin $>50 \mathrm{ng} / \mathrm{mL}(n=183)$ & Value of $\mathrm{p}^{2}$ \\
\hline Mean age, years (SD) & $54 \pm 15$ & $51 \pm 14$ & 0.2909 \\
\hline Male, \% (n) & $19.4(7)$ & $16.9(31)$ & 0.8096 \\
\hline Mean body mass index, $\mathrm{kg} / \mathrm{m}^{2}$ (SD) & $31.3 \pm 7.0$ & $29.6 \pm 6.9$ & 0.1865 \\
\hline Upper respiratory tract infection, $\%(n)^{4}$ & $83.3(30)$ & $92.3(169)$ & 0.1094 \\
\hline Lower respiratory tract infection, $\%(n)^{4}$ & $75.0(27)$ & $82.5(151)$ & 0.3487 \\
\hline Diabetes mellitus, $\%(n)^{4}$ & $13.9(5)$ & $15.8(29)$ & 1.0000 \\
\hline Autoimmune condition(s), \% (n) ${ }^{4,5}$ & $50.0(18)$ & $52.5(96)$ & 0.8560 \\
\hline Atopy, \% (n) ${ }^{4}$ & $33.3(12)$ & $30.6(56)$ & 0.8440 \\
\hline Other allergy, \% (n) ${ }^{4}$ & $44.4(16)$ & $40.4(74)$ & 0.7124 \\
\hline Corticosteroid therapy, \% (n) & $30.5(11)$ & $36.6(67)$ & 0.5702 \\
\hline Mean total $\lg G, \mathrm{mg} / \mathrm{dL}(\mathrm{SD})^{6}$ & $805 \pm 218$ & $775 \pm 207$ & 0.4555 \\
\hline Subnormal lgG1, \% (n) & $69.4(25)$ & $66.7(122)$ & 0.8472 \\
\hline Subnormal lgG2, \% (n) & $13.9(5)$ & $8.7(16)$ & 0.3538 \\
\hline Subnormal lgG3, \% (n) & $61.1(22)$ & $66.7(122)$ & 0.5662 \\
\hline Subnormal lgG4, \% (n) & $2.8(1)$ & $7.7(14)$ & 0.4750 \\
\hline Subnormal lgA, \% (n) & $2.8(1)$ & $4.9(9)$ & 1.0000 \\
\hline Subnormal IgM, \% (n) & $22.2(8)$ & 10.4 (19) & 0.0565 \\
\hline
\end{tabular}

${ }^{1}$ Abbreviations: $S D$ standard deviation. Subnormal $\lg$ levels were defined as those $>2$ SD below the respective means: $\operatorname{lgG} 1<4.2 \mathrm{~g} / \mathrm{L}(<422 \mathrm{mg} / \mathrm{dL}) ; \operatorname{lgG} 2<1.2 \mathrm{~g} / \mathrm{L}$ $(<117 \mathrm{mg} / \mathrm{dL}) ; \mathrm{lgG3}<0.4 \mathrm{~g} / \mathrm{L}(<41 \mathrm{mg} / \mathrm{dL}) ; \mathrm{lgG} 40 \mathrm{~g} / \mathrm{L}(<1 \mathrm{mg} / \mathrm{dL}) ; \mathrm{lgA}<700 \mathrm{mg} / \mathrm{L}(<70 \mathrm{mg} / \mathrm{dL}) ;$ and $\mathrm{lgM}<400 \mathrm{mg} / \mathrm{L}(<40 \mathrm{mg} / \mathrm{dL})[15]$

${ }^{2}$ Comparisons were made with Fisher's exact test (two-tailed). These are nominal values of $\mathrm{p}$. Bonferroni correction for 17 comparisons yielded a revised $\mathrm{p}$ for significance of $<0.0020$

${ }^{3}$ Upper respiratory tract infection was defined as reports of sinusitis, otitis media, mastoiditis, pharyngitis, and tonsillitis. Lower respiratory tract infection was defined as reports of bronchitis, pneumonia, and bronchiectasis

${ }^{4}$ These conditions were diagnosed before referral for the present evaluations

${ }^{5}$ These autoimmune conditions ( $n$ ) were diagnosed in 114 of 219 patients (52.1\%): Hashimoto thyroiditis (44); rheumatoid arthritis (27); Sjögren syndrome (26); systemic lupus erythematosus (20); psoriatic arthritis (8); ankylosing spondylitis (6); Graves disease, psoriasis, and Raynaud phenomenon (5 each); inflammatory arthritis (3); autoimmune diabetes, Crohn disease, multiple sclerosis, polyarthritis with iritis/uveitis, and sarcoidosis, (2 each); and chronic inflammatory demyelinating polyneuropathy, Guillain-Barré syndrome, mixed connective tissue disorder, myasthenia gravis, polymyositis, transverse myelitis, Schnitzler syndrome, Sweet syndrome, ulcerative colitis, undifferentiated connective tissue disease, and vitiligo (1 each). Two or more autoimmune conditions were diagnosed in 46 of 219 patients (21.0\%)

${ }^{6}$ Proportions of patients with and without MBL $\leq 50 \mathrm{ng} / \mathrm{mL}$ who had total $\operatorname{lgG}<7.0 \mathrm{~g} / \mathrm{L}(<700 \mathrm{mg} / \mathrm{dL})$ did not differ significantly $(38.9 \%(n=14) \mathrm{vs}$. 39.0\% $(n=71) ; \mathrm{p}=\sim 1.0000)$

(12.0\%) had plasma MBL < $50 \mathrm{ng} / \mathrm{mL}$ [17]. Twenty-seven of 164 healthy white Spanish adults (16.5\%) had $M B L 2$ genotypes that predicted low MBL levels (mean serum MBL $62 \pm 9$ (SD) ng/mL) [18]. Thus, the proportion of the present patients with $\mathrm{MBL} \leq 50 \mathrm{ng} / \mathrm{mL}$ is similar to proportions of control adults in two healthy western European cohorts with low MBL levels or $M B L 2$ genotypes that predict low MBL levels. First and second MBL levels in 14 of the present patients were similar, consistent with a report that variation of MBL levels in healthy adults over time is not significant [19]. General clinical and laboratory characteristics of the present patients with $\mathrm{MBL} \leq 50 \mathrm{ng} / \mathrm{mL}$ and those with $\mathrm{MBL}>50 \mathrm{ng} / \mathrm{mL}$ did not differ significantly.

$\mathrm{MBL} \leq 50 \mathrm{ng} / \mathrm{mL}$ was not significantly associated with age at IgGSD diagnosis in the present patients (mean age $51 \mathrm{y}$ ). In common variable immunodeficiency, the mean age of disease onset was significantly lower in patients with $M B L 2$ exon 1 mutations and promoter haplotypes that predict low MBL production than in patients with wild-type $M B L 2$ alleles (15 y vs. 25 y, respectively) [20].

MBL levels and BMI were inversely associated in a correlation analysis, although this association was not especially strong. Mean MBL levels of the present patients with $\mathrm{BMI}<30.0 \mathrm{~kg} / \mathrm{m}^{2}$ and those with $\mathrm{BMI} \geq 30.0$ $\mathrm{kg} / \mathrm{m}^{2}$ did not differ significantly. BMI was not a significant predictor of $\mathrm{MBL} \leq 50 \mathrm{ng} / \mathrm{mL}$ in a logistic regression. In a study of German adults not selected for IgGSD or frequent or severe respiratory tract infection, mean plasma MBL levels in severely obese and healthy, lean subjects did not differ significantly [21]. In obese German and Swedish subjects, MBL levels did not change significantly after weight loss [21, 22]. MBL mRNA is not expressed in adipose tissue [22].

Mean/median MBL levels of the present men and women did not differ significantly. In healthy American military beneficiaries ( $83 \%$ Caucasians), the prevalence of serum $\mathrm{MBL}<50 \mathrm{ng} / \mathrm{mL}$ was significantly lower in men than women ( $14 \%$ vs. $20 \%$, respectively) and the 


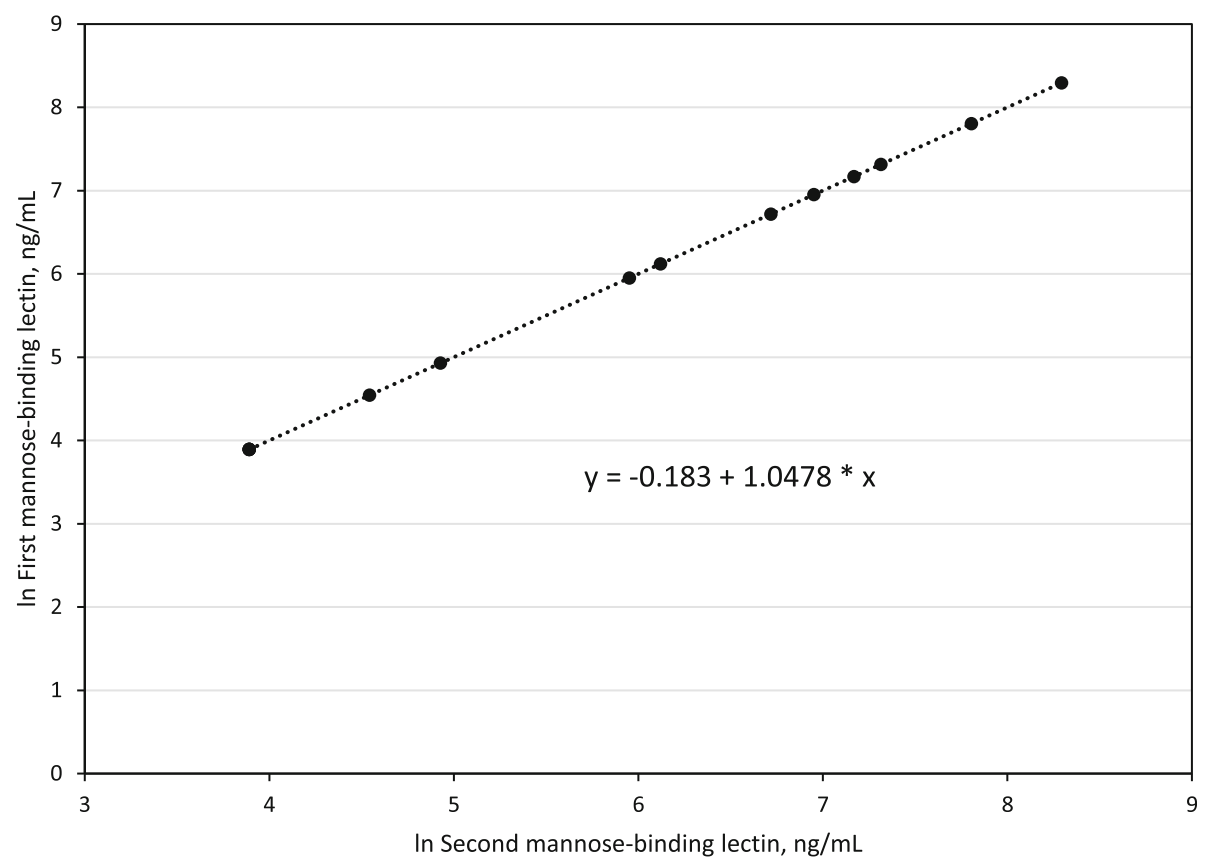

Fig. 1 First and second serum mannose-binding levels in 14 adults with lgG subclass deficiency. Correlation of first and second serum mannosebinding levels expressed as natural logarithms (In) in 14 adults with IgG subclass deficiency. The median interval between the first and second measurements was 125 days (range 18-1031). The lowest point represents observations on four patients. For In-transformed data: adjusted $r^{2}=$ 0.9675; Pearson correlation coefficient 0.9849; $p<0.0001$. For non-transformed data: adjusted $r^{2}=0.7933$; Pearson correlation coefficient $0.8935 ; p$ $<0.0001$ (graph not shown)

prevalence of $\mathrm{MBL}>2000 \mathrm{ng} / \mathrm{mL}$ was significantly higher in men than women ( $28 \%$ vs. $21 \%$, respectively) [23]. In a review of 84 studies, Falagas et al. concluded that males in all age groups develop respiratory tract infections (except sinusitis, otitis externa, and probably tonsillitis) more frequently than females, and that differences in sites of respiratory tract infection between males and females are probably influenced by diverse genetic, biochemical, anatomical, and socioeconomic factors [24].

The prevalence of upper and lower respiratory tract infection was lower in the present patients with MBL $\leq 50$ $\mathrm{ng} / \mathrm{mL}$ than in patients with MBL $>50 \mathrm{ng} / \mathrm{mL}$, but these differences were not statistically significant. In British adults with chronic obstructive pulmonary disease, those

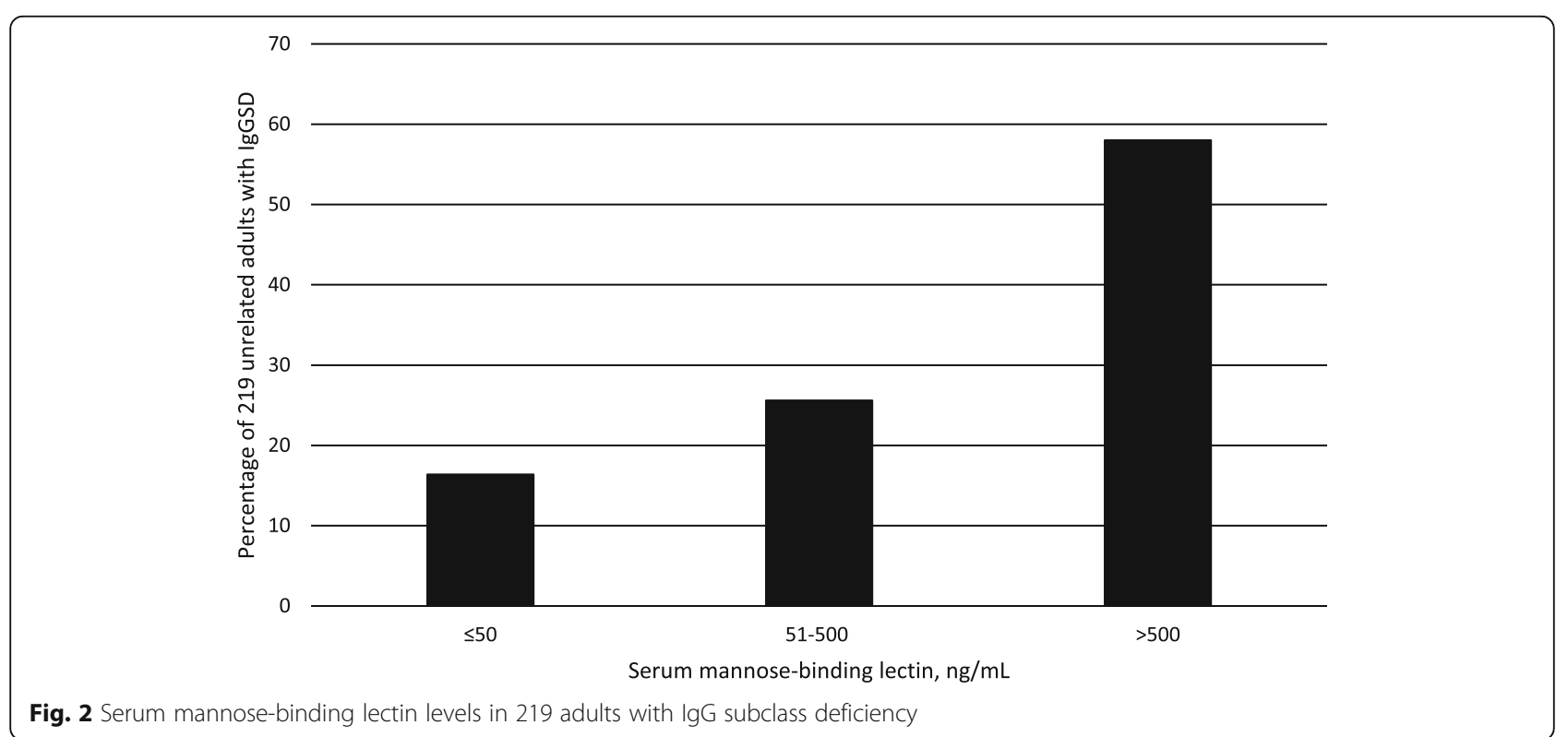


Table 2 Subnormal serum IgG subclass levels in 219 adults with IgG subclass deficiency

\begin{tabular}{|c|c|c|c|}
\hline Subnormal lgG subclass immunophenotypes ${ }^{a}$ & $\begin{array}{l}\text { Mannose-binding lectin } \leq 50 \mathrm{ng} / \mathrm{mL} \\
(n=36)\end{array}$ & $\begin{array}{l}\text { Mannose-binding lectin }>50 \mathrm{ng} / \mathrm{mL} \\
(n=183)\end{array}$ & Value of $\mathrm{p}^{2}$ \\
\hline IgG1 alone, \% (n) & $38.9(14)$ & $29.5(54)$ & 0.3245 \\
\hline $\operatorname{lgG} 2$ alone, \% (n) & 0 & $0.55(1)$ & 1.0000 \\
\hline lgG3 alone, \% (n) & $25.0(9)$ & $29.0(53)$ & 0.6906 \\
\hline $\operatorname{lgG} 1 / \operatorname{lgG} 3, \%(n)$ & $22.2(8)$ & $25.7(47)$ & 0.8338 \\
\hline $\operatorname{lgG} 1 / \operatorname{lgG} 4, \%(n)$ & 0 & $3.3(6)$ & 0.5925 \\
\hline $\operatorname{lgG} 2 / \operatorname{lgG} 3, \%(n)$ & $8.3(3)$ & $1.1(2)$ & 0.0324 \\
\hline $\operatorname{lgG} 3 / \operatorname{lgG} 4, \%(n)$ & 0 & $2.2(4)$ & 1.0000 \\
\hline $\operatorname{lgG} 1 / \lg \mathrm{lg} / \operatorname{lgG} 3, \%(\mathrm{n})$ & $2.8(1)$ & $6.6(12)$ & 0.6992 \\
\hline $\operatorname{lgG} 1 / \operatorname{lgG} 3 / \operatorname{lgG} 4, \%(n)$ & $2.8(1)$ & $1.6(3)$ & 0.5151 \\
\hline $\operatorname{lgG} 2 / \operatorname{lgG} 3 / \operatorname{lgG} 4, \%(\mathrm{n})$ & 0 & $0.55(1)$ & 1.0000 \\
\hline
\end{tabular}

${ }^{\mathrm{a}}$ Subnormal $\mathrm{lgG}$ subclass levels were defined as those $>2$ standard deviations below the respective $\mathrm{means}: \mathrm{lgG} 1<4.2 \mathrm{~g} / \mathrm{L}(<422 \mathrm{mg} / \mathrm{dL}) ; \mathrm{lgG} 2<1.2 \mathrm{~g} / \mathrm{L}(<117 \mathrm{mg} /$ $\mathrm{dL}) ; \operatorname{lgG} 3<0.4 \mathrm{~g} / \mathrm{L}(<41 \mathrm{mg} / \mathrm{dL}) ;$ and $\operatorname{lgG} 40 \mathrm{~g} / \mathrm{L}(<1 \mathrm{mg} / \mathrm{dL})[15]$

${ }^{2}$ Comparisons were made with Fisher's exact test (two-tailed). These are nominal values of $\mathrm{p}$. Bonferroni correction for 10 comparisons yielded a revised $\mathrm{p}$ for significance of $<0.0050$

with $M B L 2$ genotypes that predicted low MBL levels had lower risk of infective exacerbations, greater lung microbiota diversity, and decreased airway inflammation [25]. In adults with rheumatoid arthritis, estimated rates of verified upper respiratory tract infections per 100 patientyears did not differ significantly between those with serum $\mathrm{MBL}<100 \mathrm{ng} / \mathrm{mL}$ and those with higher MBL levels [26].

Lower respiratory tract infection was reported by $86 \%$ of the present patients with IgGSD, but we observed no significant relationships of MBL and lower respiratory tract infection. The frequencies of $M B L 2$ alleles and genotypes in Spanish white adults with community-acquired pneumonia and control subjects did not differ significantly, but $M B L 2$ genotypes that predicted low MBL levels were associated with significantly greater severity of illness and risk of death [18]. In a case-control study of Spanish adults, there was no significant relationship of $M B L 2$ genotypes and pneumococcal community-acquired pneumonia (with or without bacteremia) [27]. In British adults with chronic obstructive pulmonary disease, the risk of infective exacerbations was significantly lower in patients with $M B L 2$ genotypes that predicted low MBL levels [25]. In Norwegian adults hospitalized for treatment of community-acquired pneumonia, $13 \%$ had serum MBL $<50 \mathrm{ng} / \mathrm{mL}$ and $34 \%$ had subnormal serum Ig levels, but MBL $<50 \mathrm{ng} / \mathrm{mL}$ was not associated with specific causative microorganisms, severity of illness, or short- or long-term outcomes [28]. Taken together, these reports suggest that associations of low MBL levels and lower respiratory tract infection in cohorts of Caucasian adults unselected for subnormal total IgG or IgG subclasses vary according to specific infective microorganisms, the presence or absence of underlying lung disease, and serum Ig levels.

Mean MBL levels of the present patients with and without diabetes did not differ significantly. MBL $\leq 50 \mathrm{ng} / \mathrm{mL}$ (dichotomous) was associated with decreased odds of diabetes in a logistic regression. In a multivariable regression on MBL levels (continuous), there was a positive association with diabetes. Mean serum MBL levels were significantly higher in Danish adults with type 1 diabetes and normal urine albumin levels than in healthy age- and sex-matched control subjects [29]. Mean serum MBL levels in Danish adults with type 2 diabetes and healthy blood donors did not differ significantly [30]. Frequencies of $M B L 2$ genotypes were similar in Swedish adults with type 2 diabetes [31] and subjects in the general European population $[17,32]$.

Autoimmune condition(s), an aggregate variable in this study, was not significantly associated with MBL $\leq 50 \mathrm{ng} / \mathrm{mL}$ or MBL levels. In Czech adults with autoimmune thyroid disease and healthy Czech control subjects, the prevalence of $M B L 2$ polymorphisms did not differ significantly [33]. In Danish adults with rheumatoid arthritis, the prevalence of undetectable serum MBL was significantly higher than that of control subjects (11\% vs. $3 \%$, respectively) [34]. Among Australian adults with rheumatoid arthritis, serum $\mathrm{MBL}<56 \mathrm{ng} / \mathrm{mL}$ was associated with a significantly increased risk of infection that required in-hospital management [35]. In Finnish patients with primary Sjögren syndrome and control subjects, there was no significant difference in $M B L 2$ genotype or allele frequencies [36]. In Dutch adults with systemic lupus erythematosus (77\% Caucasian), functional MBL activity $<10 \%$ of normal was not associated with increased infection risk [37]. In contrast, homozygosity for $M B L 2$ alleles that predicted low MBL levels was higher in Danish patients with systemic lupus erythematosus than in control subjects, and was associated with significantly greater infection risk [38]. 
Atopy, defined as a dichotomous variable in this study, was not significantly associated with $\mathrm{MBL} \leq 50 \mathrm{ng} / \mathrm{mL}$ or MBL levels. In Finnish adults with asthma and control subjects, there was no significant association of $M B L 2$ genotype and atopy (defined as a wheal reaction to one or more of 22 allergens applied by skin pricks) [39].

MBL $\leq 50 \mathrm{ng} / \mathrm{mL}$ was not significantly associated with subnormal IgG subclasses, IgA, or IgM. In another study, five of 12 American adults with chronic rhinosinusitis and $\mathrm{MBL}<100 \mathrm{ng} / \mathrm{mL}$ also had subnormal IgG subclass levels, including three with subnormal IgG3 [40]. In contrast, $\mathrm{MBL}<20 \mathrm{ng} / \mathrm{mL}$ in Finnish adults with IgA $<0.05 \mathrm{~g} / \mathrm{L}$, alone or in combination with subnormal IgG subclass levels, was not associated with increased risk of respiratory infection [41].

Decreased IgG responses to 23-valent pneumococcal polysaccharide vaccination are common in adults with IgGSD [10, 12, 42, 43]. In Dutch adults with recurrent respiratory tract infections who were unselected for total IgG or IgG subclass levels, responses to 23-valent pneumococcal polysaccharide vaccination were similar in subjects with or without functional MBL activity < $10 \%$ of normal [11].

A strength of this study is that this sample size provides statistical power to estimate independent joint effects in multivariable models. Limitations of this study include lack of: control subjects; identification of microorganisms associated with infections; MBL2 genotyping; evaluation of lectin and opsonization pathways; and evaluation of 23-valent pneumococcal vaccination responses. Family studies and longitudinal follow-up of the present patients were beyond the scope of this study.

\section{Conclusions}

We conclude that the proportion of the present IgGSD patients with serum MBL $\leq 50 \mathrm{ng} / \mathrm{mL}$ is similar to that of healthy European adults. MBL $\leq 50 \mathrm{ng} / \mathrm{mL}$ was not significantly associated with independent variables we studied.

\section{Abbreviations}

BMl: Body mass index; Ig: Immunoglobulin; IgGSD: IgG subclass deficiency; MBL: Mannose-binding lectin; SD: Standard deviation

\section{Acknowledgements}

Not applicable.

\section{Funding}

Southern Iron Disorders Center and Brookwood Biomedical provided financial support for study design and data collection, analysis, and interpretation.

\section{Availability of data and materials}

All data generated or analysed during this study are included in this published article.

\section{Authors' contributions}

JaCB conceived the study, evaluated patients, compiled data, performed statistics, and drafted the manuscript. JCIB compiled data and performed statistics. LFB evaluated patients and compiled data. Each author contributed substantively to the manuscript development and agreed with its final form. All authors read and approved the final manuscript.

\section{Ethics approval and consent to participate}

This work was performed according to the principles of the Declaration of Helsinki [44]. Western Institutional Review Board granted an exemption for performance of this study under 45 CFR 46.101(b)(4) on 18 October 2018 (submission 2535878-44170911; 2 October 2018). Obtaining informed consent was not required because this study involves retrospective chart review and analyses of observations recorded in routine medical care.

\section{Consent for publication}

Not applicable.

\section{Competing interests}

The authors declare that they have no competing interests.

\section{Publisher's Note}

Springer Nature remains neutral with regard to jurisdictional claims in published maps and institutional affiliations.

\section{Author details}

'Department of Medicine, University of Alabama at Birmingham, Birmingham, AL, USA. ${ }^{2}$ Southern Iron Disorders Center, 2022 Brookwood Medical Center Drive, Suite 626, Birmingham, AL 35243, USA. ${ }^{3}$ Department of Medicine, Brookwood Medical Center, Birmingham, AL, USA. ${ }^{4}$ Brookwood Biomedical, Birmingham, AL, USA.

Received: 11 November 2018 Accepted: 16 May 2019

Published online: 22 May 2019

\section{References}

1. Turner MW, Hamvas RM. Mannose-binding lectin: structure, function, genetics and disease associations. Rev Immunogenet. 2000;2:305-22.

2. Eisen DP, Minchinton RM. Impact of mannose-binding lectin on susceptibility to infectious diseases. Clin Infect Dis. 2003;37:1496-505.

3. Garred P, Larsen F, Madsen HO, Koch C. Mannose-binding lectin deficiency-revisited. Mol Immunol. 2003;40:73-84.

4. Larsen F, Madsen HO, Sim RB, Koch C, Garred P. Disease-associated mutations in human mannose-binding lectin compromise oligomerization and activity of the final protein. J Biol Chem. 2004;279:21302-11.

5. Dean MM, Minchinton RM, Heatley S, Eisen DP. Mannose binding lectin acute phase activity in patients with severe infection. J Clin Immunol. 2005; 25:346-52.

6. Madsen HO, Garred P, Thiel S, Kurtzhals JA, Lamm LU, Ryder LP, et al. Interplay between promoter and structural gene variants control basal serum level of mannan-binding protein. J Immunol. 1995;155:3013-20.

7. Rantala A, Lajunen T, Juvonen R, Bloigu A, Silvennoinen-Kassinen S, Peitso A, et al. Mannose-binding lectin concentrations, MBL2 polymorphisms, and susceptibility to respiratory tract infections in young men. J Infect Dis. 2008; 198:1247-53.

8. Vidarsson G, Dekkers G, Rispens T. IgG subclasses and allotypes: from structure to effector functions. Front Immunol. 2014;5:1-17.

9. Barton JC, Bertoli LF, Barton JC. Comparisons of CVID and IgGSD: referring physicians, autoimmune conditions, pneumovax reactivity, immunoglobulin levels, blood lymphocyte subsets, and HLA-A and -B typing in 432 adult index patients. J Immunol Res. 2014;2014:1-10.

10. Bousfiha A, Jeddane L, Picard C, Ailal F, Bobby GH, Al-Herz W, et al. The 2017 IUIS phenotypic classification for primary immunodeficiencies. J Clin Immunol. 2018;38:129-43.

11. van Kessel DA, Hoffman TW, van Velzen-Blad H, Zanen P, Rijkers GT, Grutters JC. Response to pneumococcal vaccination in mannose-binding lectindeficient adults with recurrent respiratory tract infections. Clin Exp Immunol. 2014;177:272-9

12. Abrahamian F, Agrawal S, Gupta S. Immunological and clinical profile of adult patients with selective immunoglobulin subclass deficiency: response to intravenous immunoglobulin therapy. Clin Exp Immunol. 2010;159:344-50.

13. American Diabetes Association. Diagnosis and classification of diabetes mellitus. Diabetes Care. 2013;36:S67-74.

14. Schauer U, Stemberg F, Rieger $\mathrm{CH}$, Borte M, Schubert S, Riedel F, et al. IgG subclass concentrations in certified reference material 470 and reference 
values for children and adults determined with the binding site reagents. Clin Chem. 2003:49:1924-9.

15. Barbee RA, Halonen M, Kaltenborn W, Lebowitz M, Burrows B. A longitudinal study of serum lgE in a community cohort: correlations with age, sex, smoking, and atopic status. J Allergy Clin Immunol. 1987;79:919-27.

16. Peduzzi P, Concato J, Kemper E, Holford TR, Feinstein AR. A simulation study of the number of events per variable in logistic regression analysis. J Clin Epidemiol. 1996;49:1373-9.

17. Steffensen R, Thiel S, Varming K, Jersild C, Jensenius JC. Detection of structural gene mutations and promoter polymorphisms in the mannanbinding lectin (MBL) gene by polymerase chain reaction with sequencespecific primers. J Immunol Meth. 2000;241:33-42.

18. Garcia-Laorden MI, Sole-Violan J, Rodriguez de CF, Aspa J, Briones ML, Garcia-Saavedra A, et al. Mannose-binding lectin and mannose-binding lectin-associated serine protease 2 in susceptibility, severity, and outcome of pneumonia in adults. J Allergy Clin Immunol. 2008;122:368-74.

19. Ytting H, Christensen IJ, Thiel S, Jensenius JC, Svendsen MN, Nielsen L, et al. Biological variation in circulating levels of mannan-binding lectin (MBL) and MBL-associated serine protease-2 and the influence of age, gender and physical exercise. Scand J Immunol. 2007;66:458-64.

20. Mullighan CG, Marshall SE, Welsh KI. Mannose binding lectin polymorphisms are associated with early age of disease onset and autoimmunity in common variable immunodeficiency. Scand I Immunol. 2000;51:111-22

21. Strack C, Baessler A, Wagner F, Bruxmeier J, Yaroslavskii O, Rousseva E, et al. Mannose-binding lectin in obesity with different degrees of metabolic syndrome abnormalities: association with atherogenic and metabolic traits. J Atheroscler Thromb. 2012;19:539-51.

22. Høyem PH, Bruun JM, Pedersen SB, Thiel S, Richelsen B, Christiansen JS, et al. The effect of weight loss on serum mannose-binding lectin levels. Clin Dev Immunol. 2012;2012:1-5.

23. Engler RJM, Klote MM, Spooner CE, Reardon GT, Halsey JF, Nelson MR. Mannan-binding lectin (MBL) serum levels in a healthy adult population: gender differences in prevalence of MBL deficiency. J Allergy Clin Immunol. 2010;125:AB10

24. Falagas ME, Mourtzoukou EG, Vardakas KZ. Sex differences in the incidence and severity of respiratory tract infections. Resp Med. 2007;101:1845-63.

25. Dicker AJ, Crichton ML, Cassidy AJ, Brady G, Hapca A, Tavendale R, et al. Genetic mannose binding lectin deficiency is associated with aimway microbiota diversity and reduced exacerbation frequency in COPD. Thorax. 2017;0:1-9.

26. Nisihara R, Skare T, Capeletto CM, Moreira L, Goeldner I, Messias-Reason I, et al. Mannose binding lectin deficiency and susceptibility to infections in patients with rheumatoid arthritis. Rheumatology (Oxford). 2016;55:951-2.

27. Garcia-Laorden MI, Rodriguez de CF, Sole-Violan J, Payeras A, Briones ML, Borderias $L$, et al. The role of mannose-binding lectin in pneumococcal infection. Eur Respir J. 2013;41:131-9.

28. Siljan WW, Holter JC, Nymo SH, Husebye E, Ueland T, Skattum L, et al. Low levels of immunoglobulins and mannose-binding lectin are not associated with etiology, severity, or outcome in community-acquired pneumonia. Open Forum Infect Dis. 2018;5:ofy002.

29. Hansen TK, Thiel S, Knudsen ST, Gravholt CH, Christiansen JS, Mogensen CE, et al. Elevated levels of mannan-binding lectin in patients with type 1 diabetes. J Clin Endocrinol Metab. 2003;88:4857-61.

30. Hansen TK, Gall MA, Tarnow L, Thiel S, Stehouwer CD, Schalkwijk CG, et al. Mannose-binding lectin and mortality in type 2 diabetes. Arch Intern Med. 2006;166:2007-13.

31. Mellbin LG, Hamsten A, Malmberg K, Steffensen R, Ryden L, Ohrvik J, et al. Mannose-binding lectin genotype and phenotype in patients with type 2 diabetes and myocardial infarction: a report from the DIGAMI 2 trial. Diabetes Care. 2010;33:2451-6.

32. Garred P, Larsen F, Seyfarth J, Fujita R, Madsen HO. Mannose-binding lectin and its genetic variants. Genes Immun. 2006;7:85-94.

33. Potlukova E, Jiskra J, Freiberger T, Limanova Z, Zivorova D, Malickova K, et al. The production of mannan-binding lectin is dependent upon thyroid hormones regardless of the genotype: a cohort study of 95 patients with autoimmune thyroid disorders. Clin Immunol. 2010;136:123-9.

34. Graudal NA, Homann C, Madsen HO, Svejgaard A, Jurik AG, Graudal HK, et al. Mannan binding lectin in rheumatoid arthritis. A longitudinal study. J Rheumatol. 1998;25:629-35

35. Carroll GJ, Makin K, Garnsey M, Bulsara M, Carroll BV, Curtin SM, et al. Undetectable mannose binding lectin and corticosteroids increase serious infection risk in rheumatoid arthritis. J Allergy Clin Immunol Pract. 2017;5: 1609-16.

36. Aittoniemi J, Pertovaara M, Hulkkonen J, Pasternack A, Hurme M, Laippala P, et al. The significance of mannan-binding lectin gene alleles in patients with primary Sjogren's syndrome. Scand J Rheumatol. 2002;31:362-5.

37. Bultink IE, Hamann D, Seelen MA, Hart MH, Dijkmans BA, Daha MR, et al. Deficiency of functional mannose-binding lectin is not associated with infections in patients with systemic lupus erythematosus. Arthritis Res Ther. 2006;8:R183

38. Garred P, Madsen HO, Halberg P, Petersen J, Kronborg G, Svejgaard A, et al. Mannose-binding lectin polymorphisms and susceptibility to infection in systemic lupus erythematosus. Arthritis Rheum. 1999:42:2145-52.

39. Aittoniemi J, Soranummi H, Rovio AT, Hurme M, Pessi T, Nieminen M, et al. Mannose-binding lectin 2 (MBL2) gene polymorphism in asthma and atopy among adults. Clin Exp Immunol. 2005;142:120-4.

40. Justice JM, Sleasman JW, Lanza DC. Recalcitrant rhinosinusitis, innate immunity, and mannose-binding lectin. Ann Otol Rhinol Laryngol. 2015;124:102-6.

41. Aittoniemi J, Koskinen S, Laippala P, Laine S, Miettinen A. The significance of IgG subclasses and mannan-binding lectin (MBL) for susceptibility to infection in apparently healthy adults with IgA deficiency. Clin Exp Immunol. 1999;116:505-8.

42. Barton JC, Bertoli LF, Barton JC, Acton RT. Selective subnormal lgG3 in 121 adult index patients with frequent or severe bacterial respiratory tract infections. Cell Immunol. 2016;299:50-7.

43. Barton JC, Bertoli LF, Barton JC, Acton RT. Selective subnormal lgG1 in 54 adults index patients with frequent or severe bacterial respiratory tract infections. J Immunol Res. 2016;2016:1405950.

44. World Medical Association Declaration of Helsinki: ethical principles for medical research involving human subjects. JAMA. 2013;310:2191-4.

\section{Ready to submit your research? Choose BMC and benefit from:}

- fast, convenient online submission

- thorough peer review by experienced researchers in your field

- rapid publication on acceptance

- support for research data, including large and complex data types

- gold Open Access which fosters wider collaboration and increased citations

- maximum visibility for your research: over $100 \mathrm{M}$ website views per year

At BMC, research is always in progress.

Learn more biomedcentral.com/submissions 